\title{
Effects of Antidepressants on Inhibitory Avoidance in Mice: A Review
}

\author{
Concepción Vinader-Caerols, Andrés Parra and Santiago Monleón \\ Department of Psychobiology, University of Valencia \\ Spain
}

\section{Introduction}

Neither the biological basis of depression (Nemeroff \& Vale, 2005; Kasper \& McEwen, 2008) nor the precise mechanism of antidepressant efficacy are completely understood (Dudra-Jastrzebska et al., 2007). Indeed, antidepressants are widely prescribed for anxiety and disorders other than depression. For example, they are the drug therapy of choice for severe anxiety disorders such as agoraphobia, generalized anxiety disorder, social phobia, obsessive-compulsive disorder and post-traumatic stress disorder (Baldessarini, 2001). Antidepressants are also employed as a therapeutic tool in disorders such as drug addition (e.g. Schatzberg, 2000), enuresis (e.g. Humphreys \& Reinberg, 2005) and chronic pain (e.g. Sindrup et al., 2005). This wide application of the effects of antidepressants and the heterogeneity of their mechanism of action suggest the existence of a common therapeutic mechanism among the disorders which these drugs are employed to treat.

A series of studies have associated major depression with significant atrophy within the hippocampus (Campbell et al., 2004; Paizanis et al., 2007). If the hippocampus plays a central role in learning and memory, alterations in this structure could well be related to the cognitive deficits observed during depressive episodes (Paizanis et al., 2007; Sahay \& Hen, 2007). The cognitive impact of antidepressants (Amado-Boccara et al., 1995) and the association between depression and memory impairment (Castaneda et al., 2008) are better understood in the framework of an emerging hypothesis that suggests that the pathogenesis and treatment of depression are involved in the plasticity of neuronal pathways (Pittenger \& Duman, 2008; Vaidya \& Duman, 2001). This plasticity would seem to modify the strength of synapses in the neural pathway involved in depression.

Given that the strength of synapses is key to the neurobiology of memory (Hebb, 1949; Morris et al., 2003), it was proposed some years ago that memory impairment - understanding memory as the trace left in the nervous system not only by individual experiences but also by genetic and epigenetic phenomena - is central to the therapeutic action of antidepressants and other psychotropic medications (Parra, 2003). This idea is complementary to the concept that depression circuits learn to malfunction and retain the memory of said malfunctioning (Parra, 2003). A similar vision of the relationship between learning, memory and depression was upheld in a later publication by Stahl (2008), who argued that, in depression, neural circuits 
learn to become inefficient in a process so called "diabolical learning" (p. 229). In this context, antidepressants would modify this memory trace through a process of neural plasticity. Moreover, due to evolutionary economy, there would be similarities among the molecular changes induced by different causes of neural plasticity, including chronic treatment with antidepressants (Duman et al., 1999) or antipsychotics (Konradi \& Heckers, 2001), long-term sensitization of the gill-withdrawal reflex of aplysia (Kandel, 2001), and delayed neural death after ischemic insult (Tsukahara et al., 1998). The similarities among these causes were discussed in a review by Parra (2003; in particular Fig. 1).

Different neurotransmission systems have been implicated in high brain functions such as learning and memory (Myhrer, 2003). Some of them are implicated in the mechanism of action of antidepressant drugs and could be responsible for the memory deficits observed with these drugs: the cholinergic system (Everitt \& Robbins, 1997), the serotonergic system (Bert et al., 2008), the noradrenergic system (Hertz et al., 2004) and the histaminergic system (Passani et al., 2000). The effects of antidepressants on memory in animals may be attributable to a combination of their neuropharmacological properties, including anticholinergic, antihistaminergic, serotonergic and noradrenergic activity (Monleón et al., 2008).

We have previously reviewed studies of the effects of antidepressants on animal memory (Monleón et al., 2008). These studies provide several valuable insights into the effects of antidepressants on memory:

1. The memory impairment produced by several antidepressants is not confined to those with anticholinergic properties.

2. Although there are relatively few studies involving chronic antidepressant administration, they reveal an absence of tolerance, which is present regardless of the mechanism responsible for the therapeutic effects of antidepressants. This lack of tolerance suggests that the influence of antidepressants on memory is related to their therapeutic effects.

3. When the effects of antidepressants are assessed, in addition to their effects on mood and anxiety, those on cognitive processes, such as learning and memory, should also be considered.

4. The plethora of studies performed with aversive stimuli is understandable given the negative nature of depression. However, the scarcity of studies involving female subjects is less comprehensible and indeed inexcusable given that the incidence of depression is much higher among women than men.

A series of experiments on the effects of different antidepressants on memory in mice have been carried out in our laboratory. These experiments have already been previously, or will be published. Specifically these experiments were programmed to study:

- The effects of acute and chronic administration of several antidepressants (amitriptyline, maprotiline and fluoxetine) on inhibitory avoidance (IA) learning.

- The effects of antidepressants on learning and memory, dissociating them from those on activity, anxiety and analgesia, which can interfere with the performance of the IA response.

- The potential state-dependent learning (SDL) of antidepressants in the IA task. SDL is a useful behavioural model to explain the influence of drugs on memory, and more specifically for the study of memory-retrieval mechanisms (Arkhipov, 1999). 
- The neurochemical substrates of IA learning in association with the neurochemical substrates of antidepressants. The cholinergic, histaminergic and serotonergic systems are involved in IA learning, and the effects of antidepressants on these systems can modulate the learning of this task.

- The possible sex differences in these effects of antidepressants.

An in-depth review of this body of work is presented herein. We will summarize and discuss the effects of the antidepressants amitriptyline, maprotiline and fluoxetine on an IA task in male and female mice, with reference to specific memory processes such as acquisition, consolidation and retrieval.

\section{Behavioural procedures: Inhibitory avoidance learning and complementary tests}

\subsection{Inhibitory avoidance learning}

Inhibitory avoidance (also called passive avoidance) is one of the most common procedures for evaluating memory in animals (e.g. Gold, 1986; Heise, 1981), as this task is learned in a single trial, which facilitates the timing of drug administration. This is crucial in discriminating the effects of a drug on different memory processes, such as acquisition, consolidation or retrieval (for a review of the usefulness of the IA procedure in memory studies, see Izquierdo \& McGaugh, 2000).

The step-through version of IA conditioning was used in the experiments reviewed here (see Figure 1). The IA apparatus (Ugo Basile, Comerio-Varese, Italy), which was placed within an isolation box, consisted of a cage made of Perspex sheets and divided into two compartments (both $15 \mathrm{~cm}$ high $\times 9.5 \mathrm{~cm}$ wide $\times 16.5 \mathrm{~cm}$ long). The chambers are separated widthwise by a flat-box partition with an automatically-operated sliding door at floor level. The floor is made of stainless steel bars of $0.7 \mathrm{~mm}$ in diameter and situated 8 $\mathrm{mm}$ apart. The starting compartment is white and continuously illuminated by a light fixture fastened to the cage lid $(24 \mathrm{~V}, 10 \mathrm{~W}$, light intensity of 290 lux at floor level, measured with the Panlux Electronic2 photometer, manufactured by GOSSEN, Nürnberg, Germany), whereas the "shock" compartment is comprised of black Perspex panels and is kept in darkness at all times.

The procedure was completed in two phases: training and test.

- Training began with a $90 \mathrm{sec}$ period of adaptation to the light compartment before the door to the other compartment was opened. This door was then opened for a maximum of $300 \mathrm{sec}$, and if the animal entered the dark compartment it received an inescapable footshock of $0.3-0.7 \mathrm{~mA}$ that was delivered for $5-10 \mathrm{sec}(0.3 \mathrm{~mA}$ and $5 \mathrm{sec}$ were the more frequently used values).

- During the test, mice were placed once again in the light compartment of the apparatus and the procedure used in the training phase was repeated, but without the shock. The time taken to enter the dark compartment, defined as latency, was automatically measured in tenths of a second and recorded manually at the end of each phase. Crossing latencies longer than $300 \mathrm{sec}$ in the test phase resulted in the trial being terminated and a latency of $300 \mathrm{sec}$ recorded. 


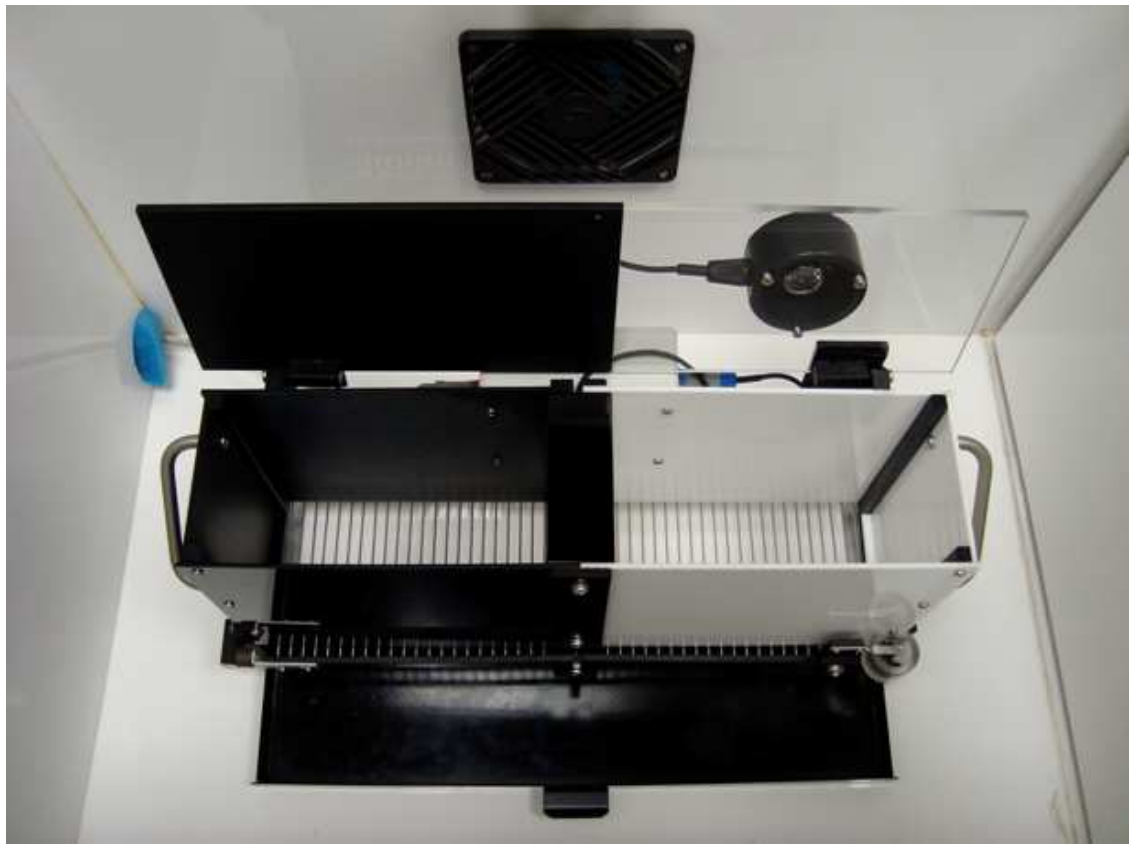

Fig. 1. Inhibitory avoidance apparatus. A step-through version of inhibitory avoidance conditioning for mice, placed inside an isolation box. The two compartments are separated widthwise by a flat-box partition.

Tests were always carried out during the dark phase of the light/dark cycle, after 7-10 days of acclimatization to the animal facility. The training-test interval was 24 hours, or 4,7 or 21 days (according to the drug administered and the administration schedule). Latencies that were longer in the test than in the training phase were considered IA.

\subsection{Complementary tests}

The effects of antidepressants on locomotor activity (e.g. Mitchell et al., 2006), anxiety (e.g. Hascoët et al., 2000) and analgesia (e.g. Duric \& McCarson, 2006) can interfere with the performance of subjects in the IA task (McGaugh \& Izquierdo, 2000). Thus, it was important for the purpose of this investigation to dissociate the effects of the drugs on learning and memory from those on activity, anxiety and analgesia (McGaugh, 1989). In order to clarify the effects of antidepressants on IA learning, the following complementary tests were used:

- Two actimeters. In one of the actimeters (ACTIMET from Cibertec S.A., Madrid, Spain) the horizontal activity was measured using an infrared photocell system. The photocell line was located $2.5 \mathrm{~cm}$ above the floor. Each photocell box measured $8.5 \mathrm{x}$ $17 \times 35 \mathrm{~cm}$ and had sixteen photocells located along its long side (see Figure 2). The animals' behaviour was continuously recorded and accumulated every minute for five minutes. 


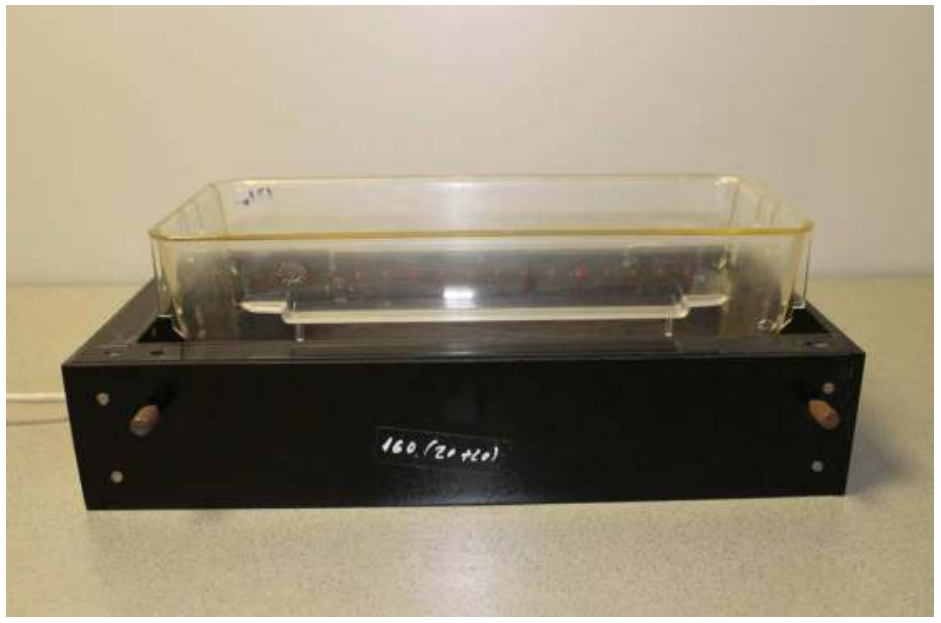

Fig. 2. Complementary tests: Actimeter. This apparatus registers the spontaneous locomotor activity of the animals by means of an infrared photocell system.

The second actimeter (Actisystem II with 'DAS 16' software from Panlab S.L., Barcelona, Spain) registered the spontaneous locomotor activity as a function of the variations produced by mouse' movements on the standard frequency $(484 \mathrm{kHz})$ of the electromagnetic field of the sensory unit $\left(35 \times 35 \mathrm{~cm}^{2}\right)$. Frequency variations were transformed into voltage changes, which, in turn, were converted into impulses that were collected by a counter when they reached a certain level (see Figure 3). The locomotor activity of the animals was monitored for five minutes.

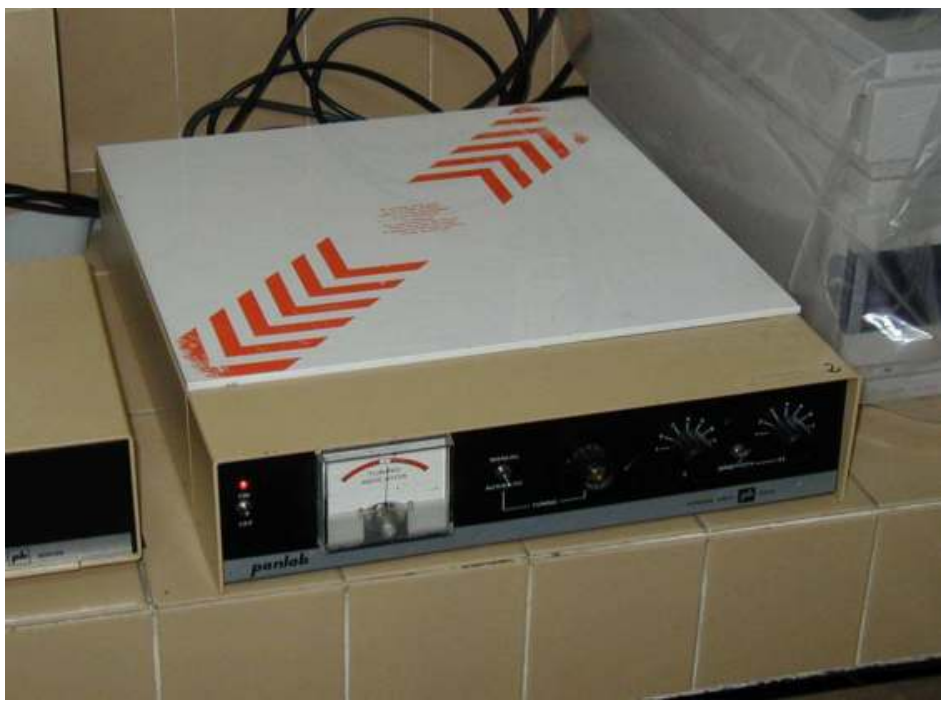

Fig. 3. Complementary tests: Sensor unit of the actimeter. This unit registers the variations of the oscillation frequency in the electromagnetic field produced by the mouse' movements. 
- An elevated plus-maze (Cibertec S.A., Madrid, Spain) (see Figure 4). This maze consisted of two open arms (30 $5 \mathrm{~cm}^{2}$ each) and two closed arms $\left(30 \times 15 \times 5 \mathrm{~cm}^{3}\right.$ each) which all fed into a common central square $\left(5 \times 5 \mathrm{~cm}^{2}\right)$. The maze was made of Plexiglas (black floor and walls) and was elevated $45 \mathrm{~cm}$ above the floor level. Sessions lasted 5 min and began with the subject being placed in an open arm (facing the central square). All sessions were videotaped with a standard VHS system for subsequent analysis. The maze was cleaned after each subject. The number of entries into open and closed arms (arm entry is defined as all four paws entering an arm) was scored by a trained observer who was unaware of the treatment applied. This provided a measurement of anxiety, the percentage of open arm entries [(open/open + closed) X 100], and a measurement of activity (number of closed arm entries). These measurements were based on former studies: File (2001), Lister (1987), and Rodgers \& Johnson (1995).

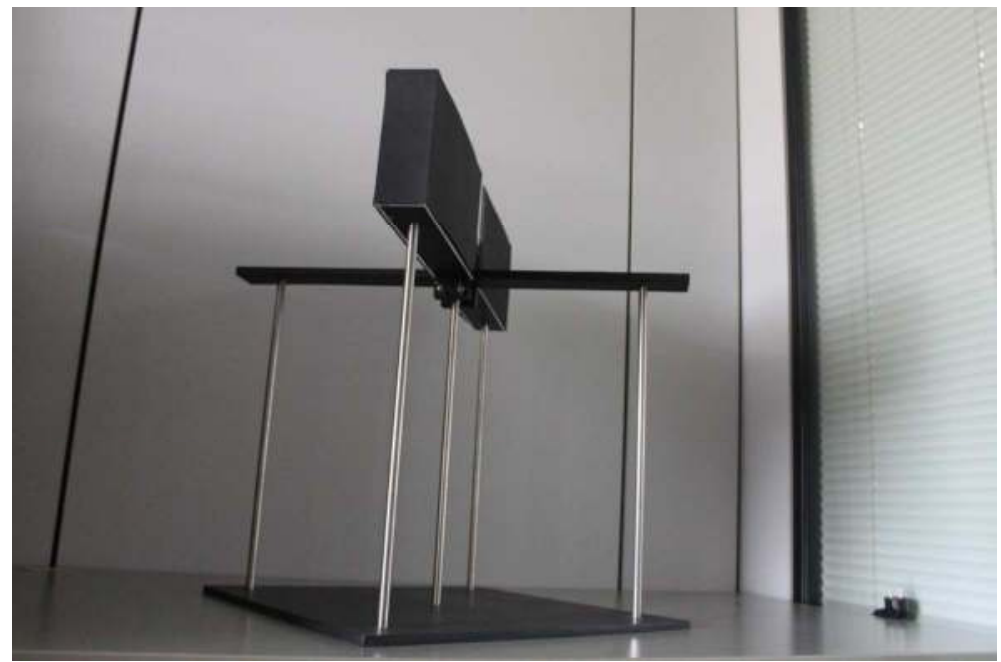

Fig. 4. Complementary tests: Elevated plus-maze for mice. This test measures anxiety and activity.

- $\quad$ A prototype of analgesia (Cibertec S.A., Madrid, Spain) (see Figure 5). This apparatus consisted of a translucent Perspex box of the same dimensions as those of one side of the avoidance apparatus, with a similar floor to the IA apparatus and a constant current source with increasing output steps of $0.059 \mathrm{~mA}$. Subjects were individually introduced into the test box and allowed a 2 min adaptation period. Subsequently, the animal received a $5 \mathrm{sec}$ shock of $0.059 \mathrm{~mA}$, increasing proportionately by $0.059 \mathrm{~mA}$ every 10 sec. The test was interrupted when the subject removed all four paws from the grid for the first time during the shock (this was done while the test was underway; and is a different criterion to that of jump threshold, which was determined on viewing the recorded sessions). The highest shock delivered was $0.77 \mathrm{~mA}$. Results were represented as flinch and jump thresholds in milliamperes. Flinch threshold was defined as the lowest shock level that elicited a detectable response, and jump threshold as the lowest shock level that elicited simultaneous removal of three paws from the grid. All tests were videotaped with a standard VHS system and later assessed. 


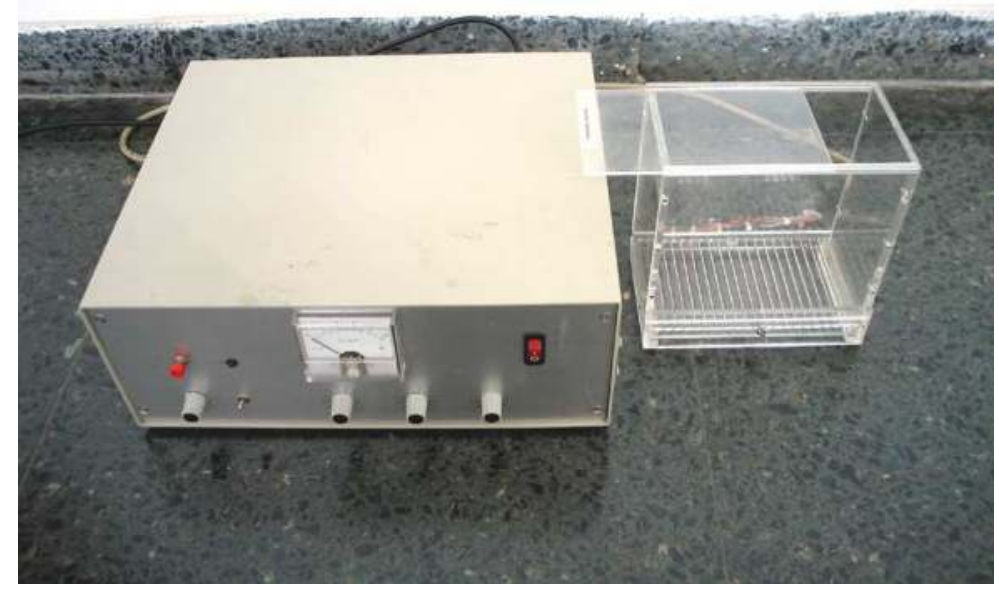

Fig. 5. Complementary tests: Prototype of analgesia. This test measures flinch and jump thresholds.

- A Morris water maze (Cibertec S.A., Madrid, Spain) (see Figure 6). This test was employed in order to evaluate the effects of maprotiline on spatial learning. The maze consisted of a circular pool made of black Plexiglas $(1 \mathrm{~m}$ diameter and $30 \mathrm{~cm}$ high), based on that described by Morris (1984) but adapted for mice (Lamberty \& Gower, 1990). The maze was filled with water to a depth of $15 \mathrm{~cm}$ and maintained at $24 \pm 1{ }^{\circ} \mathrm{C}$. A small platform $(6 \times 6 \mathrm{~cm})$ was submerged $1 \mathrm{~cm}$ below the surface of the water in the target quadrant. Several extramaze cues, including laboratory equipment and posters, were available around the pool. During the acquisition phase mice performed 4 trials per day for 4 consecutive days. After an inter-trial interval of $30 \mathrm{sec}$ the trial began by placing the mouse on the platform for $30 \mathrm{sec}$. Mice were then placed in the water with their noses pointing towards the wall at one of the three starting points in a random manner. During this phase animals were allowed $60 \mathrm{sec}$ to find the hidden platform. If unable to do so, they were led to it by the experimenter. Animals were allowed to stay on the platform for $30 \mathrm{sec}$, regardless of whether they had found it independently or after guidance. Starting positions were chosen at random from the three possible sites around the pool's perimeter, which were situated in each of the quadrants not occupied by the platform. The starting positions were determined so that two successive trials never began from the same position. In a retention phase (probe trial) carried out on the fifth day the platform was removed and mice were allowed to swim for $100 \mathrm{sec}$ after starting in the opposite quadrant to that in which was the platform during acquisition. A video-camera recorded the probe trials. The measures obtained were escape latency (time to reach the submerged platform) during the acquisition trials and search time in each quadrant during the probe trial. The drug was administered $30 \mathrm{~min}$ before each experimental session. The use of this test was occasional in our research and complementary to the IA learning. 


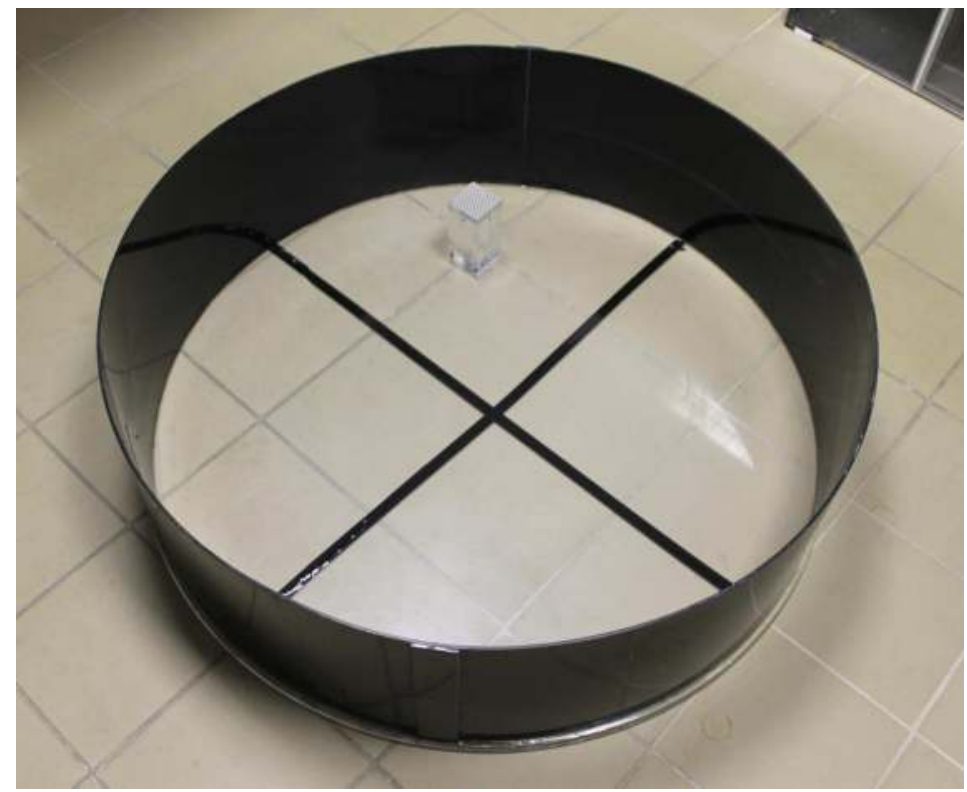

Fig. 6. Morris water maze for mice. This test evaluates spatial learning.

\section{Antidepressant and complementary drugs}

The following antidepressant drugs were used in these experiments:

- Amitriptyline hydrochloride (Sigma-Aldrich Química, Madrid, Spain). This tricyclic antidepressant is a mixed serotonergic and noradrenergic uptake inhibitor with a strong anticholinergic and antihistaminergic effect (Richelson, 2003). Amitriptyline is one of the most-studied antidepressants with regard to effects on cognitive functions, including memory and tends to be the standard against which newer compounds are compared (Thompson, 1991). Among currently available antidepressants, amitriptyline is the most potent in blocking muscarinic cholinergic receptors (Frazer, 1997; Owens et al., 1997, Richelson, 2001; Stahl, 1998). The effects of acute administration of amitriptyline on IA were evaluated at doses of 2.5, 5, 7.5, 10, 15, 20 and $30 \mathrm{mg} / \mathrm{kg}$. Chronic administration of the highest dose was also evaluated.

- Maprotiline hydrochloride (Ciba-Geigy A.G., Basel, Switzerland). This is a tetracyclic antidepressant prescribed largely for the elderly (Gareri et al., 2000). It selectively inhibits norepinephrine reuptake and has a high antihistaminergic activity, a modest anticholinergic activity and a low serotonin reuptake inhibitory effect (Gareri et al., 2000; Harvey et al., 2000; Pinder et al., 1977; Redrobe \& Bourin, 1997; Richelson \& Nelson, 1984). This compound has fewer side effects than classic tricyclic antidepressants (Grüter \& Pöldinger, 1982), but what it does have in common is the impairment of memory (Gareri et al., 2000). The effects of acute administration of Maprotiline on IA were evaluated at doses of 2.5, 5, 10, 15, 20 and $25 \mathrm{mg} / \mathrm{kg}$. The 5, 10 and $20 \mathrm{mg} / \mathrm{kg}$ doses were also evaluated after chronic administration and the effects of the 15,20 and $25 \mathrm{mg} / \mathrm{kg}$ doses on spatial learning were evaluated after subchronic administration. 
- Fluoxetine hydrochloride (Eli Lilly, Indianapolis, U.S.A.). This is a selective serotonin reuptake inhibitor with little affinity for muscarinic, histaminic H1, serotonergic 5-HT1 or 5-HT2, or noradrenergic alpha 1 or alpha 2 receptors (Beasley et al., 1992; Stark et al., 1985). The effects of acute administration of fluoxetine on IA were evaluated at doses of $5,10,15$ and $20 \mathrm{mg} / \mathrm{kg}$. Chronic administration of the highest dose was also analysed.

The following complementary drugs were also used in some of the experiments:

- Piracetam (Sigma-Aldrich Química, Madrid, Spain), whose mechanism of action is still unclear but which appears to be a non-specific activator of neuronal excitability (Gouliaev \& Senning, 1994). A $100 \mathrm{mg} / \mathrm{kg}$ dose of piracetam was evaluated in the IA procedure after both acute and chronic administration and in combination with amitriptyline (100 mg/ $\mathrm{kg}$ dose of piracetam and $30 \mathrm{mg} / \mathrm{kg}$ of amitriptyline).

- Oxotremorine sesquifumarate (Sigma-Aldrich Química, Madrid, Spain), a centrally acting muscarinic cholinergic agonist (Introini-Collison \& Baratti, 1992). The effects of acute administration of oxotremorine on IA were evaluated at doses of 0.05 and 0.1 $\mathrm{mg} / \mathrm{kg}$ and in combination with amitriptyline $(0.05 \mathrm{mg} / \mathrm{kg}$ dose of oxotremorine and 5 , 10 or $15 \mathrm{mg} / \mathrm{kg}$ of amitriptyline; $0.1 \mathrm{mg} / \mathrm{kg}$ dose of oxotremorine and 5, 7.5 or 10 $\mathrm{mg} / \mathrm{kg}$ of amitriptyline).

- Physostigmine salicylate (Sigma-Aldrich Química, Madrid, Spain), a centrally acting anticholinesterase (Boccia et al., 2003). The effects of acute administration of physostigmine on IA were evaluated at doses of $0.15,0.3$ and $0.6 \mathrm{mg} / \mathrm{kg}$, and each of these doses were also combined with $5 \mathrm{mg} / \mathrm{kg}$ of amitriptyline.

- L-Histidine monohydrochloride monohydrate (Sigma-Aldrich Química, Madrid, Spain), a precursor of histamine (Prell et al., 1996), was evaluated in the IA procedure, given alone $(250,500$ and $1000 \mathrm{mg} / \mathrm{kg}$ ) and in combination with amitriptyline (1000 $\mathrm{mg} / \mathrm{kg}$ of l-histidine and 2.5 or $10 \mathrm{mg} / \mathrm{kg}$ of amitriptyline).

- Pyrilamine maleate (Sigma-Aldrich Química, Madrid, Spain), a histamine H1 postsynaptic receptor antagonist (Yanai et al., 1990), was administered alone (5, 10 and $20 \mathrm{mg} / \mathrm{kg})$ and with amitriptyline $(20 \mathrm{mg} / \mathrm{kg}$ of pyrilamine and $2.5,5$, or $10 \mathrm{mg} / \mathrm{kg}$ of amitriptyline) in order to study their effects on IA.

All drugs were diluted in physiological saline and intraperitoneally injected at a volume of $0.01 \mathrm{ml} / \mathrm{g}$ body weight. Doses were calculated as the weight of the base. Control groups received the same volume of physiological saline.

\section{Results}

\subsection{Amitriptyline}

Table 1 summarizes the results and some procedural details of the experiments carried out with amitriptyline. They are grouped below in seven categories: 1) Effects of acute administration of amitriptyline on IA; 2) Effects of chronic administration of amitriptyline on IA; 3) Modulation of the acute and chronic effects of amitriptyline by piracetam; 4) Modulation of the acute effects of amitriptyline by the cholinergic system; 5) Modulation of the acute effects of amitriptyline by the serotonergic system; 6) Modulation of the acute effects of amitriptyline by the histaminergic system; 7) Study of potential state-dependent learning. 


\begin{tabular}{|c|c|c|c|c|c|c|c|c|c|}
\hline Strain & Sex & Doses (mg/kg) & Tr. & Administration & Learning & Activity & Anxiety & SDL & Reference \\
\hline OF1 & M & $7.5,15,30$ & A & Post-training & - & & & & Everss et al., 1999 \\
\hline CD1 & M & $7.5,15,30$ & $\mathrm{~A}$ & Post-training & - & $-(15,30)$ & 0 & & Parra et al., 2002 \\
\hline CD1 & $\mathrm{F}$ & 15 & A & Post-training & 0 & - & 0 & & Parra et al., 2002 \\
\hline CD1 & $\mathrm{F}$ & $7.5,30$ & $\mathrm{~A}$ & Post-training & - & $-(30)$ & 0 & & Parra et al., 2002 \\
\hline CD1 & M, F & 2.5 & $\mathrm{~A}$ & Pre-training & 0 & & & & Parra et al., 2009 \\
\hline CD1 & M & 5 & $\mathrm{~A}$ & Pre-training & 0 & & & & Parra et al., 2009 \\
\hline CD1 & $\mathrm{F}$ & 5 & A & Pre-training & - & & & & Parra et al., 2009 \\
\hline CD1 & M, F & 10,20 & A & Pre-training & - & & & & Parra et al., 2009 \\
\hline CD1 & M & 20 & A & Pre-training & - & & & & $\begin{array}{c}\text { González-Pardo et al., } \\
2008 \\
\end{array}$ \\
\hline CD1 & M, F & $2.5,5,10$ & $\mathrm{~A}$ & Pre-training & 0 & & & & Parra et al., 2010 \\
\hline CD1 & $\mathrm{M}, \mathrm{F}$ & 10 & A & Pre-training & - & & & & Ferrer-Añó, 2008 \\
\hline CD1 & $\mathrm{M}, \mathrm{F}$ & $5,7.5,10,15,20,30$ & A & Pre-training & - & & & & Urquiza, 2007 \\
\hline CD1 & $\mathrm{M}, \mathrm{F}$ & 30 & $\mathrm{~A}$ & Post-training & 0 & & & & Urquiza, 2007 \\
\hline CD1 & $\mathrm{M}, \mathrm{F}$ & 30 & A & Post-training & - & & & & Everss et al., 2005 \\
\hline CD1 & M & 30 & $\mathrm{C}$ & Pre-training & - & & & & Parra et al., 2006 \\
\hline CD1 & $\mathrm{F}$ & 30 & $\mathrm{C}$ & Pre-training & 0 & & & & Parra et al., 2006 \\
\hline CD1 & M, F & 30 & $\mathrm{C}$ & Post-training & 0 & 0 & 0 & & Parra et al., 2006 \\
\hline CD1 & $\mathrm{M}, \mathrm{F}$ & 30 & $\mathrm{C}$ & $\begin{array}{l}\text { Pre-training and } \\
\text { Post-training } \\
\end{array}$ & - & 0 & 0 & & Everss et al., 2005 \\
\hline CD1 & $\mathrm{M}, \mathrm{F}$ & 30 & $\mathrm{~A}$ & Pre-training & - & & & $0 \mathrm{a}$ & Arenas et al., 2006 \\
\hline $\mathrm{CD} 1$ & M & 30 & A & Pre-test & 0 & & & $0 \mathrm{a}$ & Arenas et al., 2006 \\
\hline CD1 & $\mathrm{F}$ & 30 & $\mathrm{~A}$ & Pre-test & - & & & $0 \mathrm{a}$ & Arenas et al., 2006 \\
\hline CD1 & $\mathrm{M}, \mathrm{F}$ & 30 & A & $\begin{array}{c}\text { Pre-training and } \\
\text { Pre-test }\end{array}$ & - & & & $0 \mathrm{a}$ & Arenas et al., 2006 \\
\hline
\end{tabular}

Abbreviations: $\mathrm{Tr} .=$ Treatment; $\mathrm{SDL}=$ state dependent learning; $\mathrm{M}=$ male; $\mathrm{F}=$ female; $\mathrm{A}=$ Acute administration; $\mathrm{SC}=$ Subchronic administration $(5$ days); $\mathrm{C}=$ Chronic administration $(21$ days); $0=$ No effect; $-=$ impairment; + = improvement; $\mathrm{a}=$ memorization deficit; $\mathrm{b}=$ memorization deficit and performance facilitation.

Table 1. Effects of different doses of amitriptyline on IA learning, activity, anxiety and SDL in mice. 
1. Effects of acute administration of amitriptyline on memory acquisition/consolidation in male OF1 mice (Everss et al., 1999) and CD1 mice of both sexes (Parra et al., 2002). Three doses of this tricyclic antidepressant $(7.5,15$ and $30 \mathrm{mg} / \mathrm{kg}$ ) were administered immediately after IA training. Subjects were tested for avoidance twenty four hours later. Amitriptyline impaired IA consolidation at doses of 7.5, 15 and $30 \mathrm{mg} / \mathrm{kg}$ in OF1 and CD1 males, and at doses of 7.5 and $30 \mathrm{mg} / \mathrm{kg}$ in CD1 females. The sex differences observed were limited to a slightly stronger effect of amitriptyline on IA in males than in females. These results indicate that acute amitriptyline administration produces retrograde amnesia in a IA task, which does not seem to be mediated by anxiolytic effects: when CD1 mice explored an elevated plus-maze during a five-minute period forty-five minutes after injection amitriptyline had no effect on anxiety (percentage of open arm entries) and induced a dose-dependent impairment of activity (number of closed arm entries), which did not affect IA, as the drug was administered after training (see conclusions regarding pharmacokinetic rationale).

Another series of experiments were performed to evaluate the effects of acute pretraining $(5,7.5,10,15,20$ and $30 \mathrm{mg} / \mathrm{kg})$ and post-training $(30 \mathrm{mg} / \mathrm{kg})$ administration of amitriptyline on IA learning (Urquiza, 2007). Results showed that only acute pretraining administration produced an impairment of learning. The dose-response relationship of the effect of amitriptyline on IA (Parra et al., 2009) was also evaluated at doses of 2.5, 5, 10 and $20 \mathrm{mg} / \mathrm{kg}$, which were administered before the training session. Results showed a clear dose-dependent impairment of amitriptyline on IA in both male and female mice. However, the $2.5 \mathrm{mg} / \mathrm{kg}$ dose had no effect on either sex, $5 \mathrm{mg} / \mathrm{kg}$ had a significant effect only on females, and 10 and $20 \mathrm{mg} / \mathrm{kg}$ produced similar significant effects in both sexes. A study evaluating changes in the brain metabolism induced by training in IA and acute administration of amitriptyline also showed an impairing effect of $20 \mathrm{mg} / \mathrm{kg}$ of this drug tested in male mice (González-Pardo et al., 2008).

2. Effects of 21-day chronic administration of amitriptyline $(30 \mathrm{mg} / \mathrm{kg})$ on the acquisition and consolidation of an IA task in male and female CD1 mice. It was also investigated whether amitriptyline, when administered after consolidation of this task, blocked memory retrieval (Parra et al., 2006). Amitriptyline given before the training phase blocked learning of IA in males, and a similar tendency was observed in females. However, when the drug was administered between training and test phases it did not affect conditioning. Anxiety and spontaneous motor activity in the elevated plus maze were also assessed in the same subjects, but no effects of amitriptyline were observed. Thus, the impairing effects of amitriptyline on IA would seem to be independent of its actions on anxiety and locomotor activity.

3. Modulation of the acute and chronic effects of amitriptyline on IA by piracetam in male and female CD1 mice (Everss et al., 2005). The purpose was to study the effects of amitriptyline on animal cognition in relation to some characteristics of its therapeutic effects. Two experiments were run. In Experiment 1, mice underwent an IA training phase sixty minutes after acute piracetam $(100 \mathrm{mg} / \mathrm{kg})$ or physiological saline administration. Immediately after the behavioural task, they received a single injection of the tricyclic antidepressant amitriptyline $(30 \mathrm{mg} / \mathrm{kg}$ ) or physiological saline. Twenty four hours later, subjects were tested for avoidance. In Experiment 2, the same doses of amitriptyline and piracetam were chronically administered. Mice underwent the IA training phase on the 
22nd day, and the test phase a further $24 \mathrm{~h}$ later. Forty-five minutes after the test, subjects were allowed to explore the elevated plus-maze for five minutes in order to assess whether the effects of amitriptyline on avoidance performance reflected general behavioural changes. The following results were obtained:

a. Acute and chronic amitriptyline impaired IA in male and female mice.

b. Piracetam counteracted the effect of acutely administered amitriptyline on IA.

c. Piracetam counteracted the effects of chronically administered amitriptyline in males but not in females in the same learning task. These effects did not seem to be mediated by non-specific drug effects on spontaneous motor activity or anxiety.

4. Modulation of the acute effects of amitriptyline on IA by the cholinergic system in male and female CD1 mice (Monleón et al., 2009; Urquiza, 2007). The amnesic effect produced by amitriptyline $(5,10$ or $15 \mathrm{mg} / \mathrm{kg}$ ) was not completely counteracted by the agonist cholinergic oxotremorine $(0.05,0.1 \mathrm{mg} / \mathrm{kg})$, but a tendency in that direction was observed. However the amnesic effect produced by $5 \mathrm{mg} / \mathrm{kg}$ of amitriptyline was counteracted by several doses of the agonist cholinergic physostigmine $(0.15,0.3$ and 0.6 $\mathrm{mg} / \mathrm{kg}$ ). In this way, physostigmine counteracted the impairing effects of amitriptyline on IA to a greater degree than oxotremorine. These differences in the effects of the two cholinergic agonists could be due to them possessing different mechanisms of action. Oxotremorine is a ligand present at all five of the muscarinic receptor subtypes (Choi et al., 1973), while physostigmine is a potent cholinesterase inhibitor (Taylor, 2001) that enhances the levels of acetylcholine, which eventually interacts with both the muscarinic and nicotinic receptor subtypes. These results demonstrate that the IA impairment produced by amitriptyline in both male and female mice is mediated, at least partially, by the cholinergic system.

5. Modulation of the acute effects of amitriptyline on IA by the serotonergic system in male and female CD1 mice (Parra et al., 2010). A combination of $2.5 \mathrm{mg} / \mathrm{kg}$ of amitriptyline with fluoxetine $(10,15$ or $20 \mathrm{mg} / \mathrm{kg})$, a selective serotonin reuptake inhibitor, revealed that the joint administration of amitriptyline $2.5 \mathrm{mg} / \mathrm{kg}$ and fluoxetine $15 \mathrm{mg} / \mathrm{kg}$ had a clear impairing effect on IA. These results highlight the involvement of the serotonergic system in the effects of amitriptyline.

6. Modulation of the acute effects of amitriptyline on IA by the histaminergic system in male and female CD1 mice (Ferrer-Añó, 2008). Amitriptyline $(10 \mathrm{mg} / \mathrm{kg})$ produced amnesic effects that were not modified in mice treated with this drug and a histaminergic precursor, L-histidine $(1000 \mathrm{mg} / \mathrm{kg})$, or a $\mathrm{H} 1$ antagonist, pyrilamine (20 $\mathrm{mg} / \mathrm{kg})$. L-histidine $(250,500$, or $1000 \mathrm{mg} / \mathrm{kg}$ ) was also administered alone and did not produce any effect on IA. No effect was produced by pyrilamine $(5,10$, or $20 \mathrm{mg} / \mathrm{kg})$ when administered alone. Neither of the two kinds of manipulation of the histamine neurotransmitter system (favouring the synthesis of histamine or blocking its action on postsynaptic receptors) had an effect on IA. Furthermore, when administered in combination with amitriptyline, these drugs did not modify the impairing effect of the antidepressant on that memory task. Given that amitriptyline has antihistaminergic properties and that the results were not modified by histaminergic manipulation, it would appear that the histaminergic system is not involved in the behaviour studied.

7. Study of potential state-dependent learning. To study the effects of the antidepressants on memory we carried out some experiments to investigate whether amitriptyline (30 $\mathrm{mg} / \mathrm{kg})$, maprotiline $(25 \mathrm{mg} / \mathrm{kg})$ and fluoxetine $(15 \mathrm{mg} / \mathrm{kg})$ produce state-dependent 
learning (SDL) in the IA task in male and female CD1 mice (Arenas et al., 2006). SDL is a phenomenon in which the retrieval of newly acquired information is possible if the subject is in the same physiological state as during the encoding phase. Independent groups were used for each pharmacological treatment and for each sex using a $2 \times 2$ experimental design. The groups were: physiological saline before training and test phases (SS); physiological saline before training and amitriptyline before phase test (SA); amitriptyline before training and physiological saline before test phase (AS); amitriptyline before training and test phases (AA). The interval between phases was of $24 \mathrm{~h}$. SDL was not detected, and results with amitriptyline can be interpreted as representing a memorization deficit (the groups that received a drug before training did not show increased test latencies, independently of the treatment administered prior to the test session; see Overton, 1974). In addition, males showed a slightly higher deterioration in their performance than females.

\subsection{Maprotiline}

Table 2 summarizes the results and some procedural details of the experiments carried out with maprotiline. They are grouped below in four categories: 1) Effects of acute and chronic administration of maprotiline on IA; 2) Effects of maprotiline on learning, anxiety, activity and analgesia; 3) Effects of subchronic administration of maprotiline on spatial learning; 4) Study of potential state-dependent learning.

1. Effects of acute and chronic administration of maprotiline $(5,10$ or $20 \mathrm{mg} / \mathrm{kg})$ on IA in male OF1 mice (Parra et al., 2000). Acute administration before training did not affect training phase latencies but did impair performance in the test at doses of 5 and 20 $\mathrm{mg} / \mathrm{kg}$. When given after training, the drug did not modify test latencies at any of the doses used. Chronic administration for 21 days (interrupted $24 \mathrm{~h}$ before training) also shortened latencies in the test, but not in training. An experiment was performed in naive animals to evaluate the acute effects of maprotiline on analgesia at the doses stated. No analgesic effect of the drug was observed. Considered as a whole, these results indicate that acute maprotiline produces anterograde amnesia, and that tolerance does not appear after 21 days of treatment.

2. Effects of a wide range of doses of maprotiline $(2.5,5,10,15,20$ and $25 \mathrm{mg} / \mathrm{kg})$ on learning, anxiety, activity and analgesia in male and female CD1 mice (Vinader-Caerols et al., 2006). IA learning was complemented with measures of anxiety and locomotor activity, which were assessed in the same animals in an elevated plus-maze. A study of the acute effects of maprotiline $(15,20$ and $25 \mathrm{mg} / \mathrm{kg})$ on analgesia was carried out in naive animals of both sexes. Maprotiline impaired IA at doses of 15, 20 and $25 \mathrm{mg} / \mathrm{kg}$. The highest dose produced an anxiolytic effect in females, and 20 and $25 \mathrm{mg} / \mathrm{kg}$ both reduced locomotor activity. Analgesia was observed with the highest dose. The IA impairment produced by maprotiline seemed to be independent of the drug's influence on anxiety, was not shadowed by an instrumental performance deficit and, at least in the case of the highest dose, appeared to be influenced by the drug's effects on analgesia. It can be hypothesised that acquisition is the memory process principally affected by maprotiline, and in particular stimuli processing. The lack of sex differences in the effects of maprotiline on IA supports the generalization of data previously reported exclusively in males. 


\begin{tabular}{|c|c|c|c|c|c|c|c|c|c|c|}
\hline Strain & Sex & $\begin{array}{c}\text { Doses } \\
(\mathrm{mg} / \mathrm{kg})\end{array}$ & Tr. & Administration & Learning & Activity & Anxiety & Analgesia & SDL & Reference \\
\hline OF1 & M & 5,20 & A & Pre-training & - & & & & & Parra et al., 2000 \\
\hline OF1 & M & 10 & A & Pre-training & 0 & & & & & Parra et al., 2000 \\
\hline OF1 & M & $5,10,20$ & A & Post-training & 0 & & & & & Parra et al., 2000 \\
\hline OF1 & M & $5,10,20$ & A & Pre-test analgesia & & & & 0 & & Parra et al., 2000 \\
\hline CD1 & $\mathrm{M}, \mathrm{F}$ & $2.5,5,10$ & A & Pre-training & 0 & 0 & 0 & & & $\begin{array}{c}\text { Vinader-Caerols et } \\
\text { al., } 2006 \\
\end{array}$ \\
\hline CD1 & $\mathrm{M}, \mathrm{F}$ & 15 & A & Pre-training & - & 0 & 0 & & & $\begin{array}{c}\text { Vinader-Caerols et } \\
\text { al., } 2006 \\
\end{array}$ \\
\hline CD1 & $\mathrm{M}, \mathrm{F}$ & 20 & A & Pre-training & - & - & 0 & & & $\begin{array}{c}\text { Vinader-Caerols et } \\
\text { al., } 2006\end{array}$ \\
\hline CD1 & M & 25 & $\mathrm{~A}$ & Pre-training & - & - & 0 & & & $\begin{array}{c}\text { Vinader-Caerols et } \\
\text { al., } 2006 \\
\end{array}$ \\
\hline CD1 & $\mathrm{F}$ & 25 & A & Pre-training & - & - & + & & & $\begin{array}{c}\text { Vinader-Caerols et } \\
\text { al., } 2006 \\
\end{array}$ \\
\hline CD1 & $\mathrm{M}, \mathrm{F}$ & 15,20 & A & Pre-test analgesia & & & & 0 & & $\begin{array}{c}\text { Vinader-Caerols et } \\
\text { al., } 2006\end{array}$ \\
\hline CD1 & $\mathrm{M}, \mathrm{F}$ & 25 & A & Pre-test analgesia & & & & + & & $\begin{array}{c}\text { Vinader-Caerols et } \\
\text { al., } 2006 \\
\end{array}$ \\
\hline CD1 & M & 15,25 & SC & Pre-training & $-S L$ & & & & & $\begin{array}{c}\text { Vinader-Caerols et } \\
\text { al., } 2002\end{array}$ \\
\hline CD1 & M & 20 & SC & Pre-training & $0 \mathrm{SL}$ & & & & & $\begin{array}{c}\text { Vinader-Caerols et } \\
\text { al., } 2002 \\
\end{array}$ \\
\hline CD1 & $\mathrm{F}$ & $15,20,25$ & SC & Pre-training & $0 S L$ & & & & & $\begin{array}{c}\text { Vinader-Caerols et } \\
\text { al., } 2002 \\
\end{array}$ \\
\hline CD1 & $\mathrm{M}, \mathrm{F}$ & $15,20,25$ & SC & Pre-actimeter & & - & & & & $\begin{array}{c}\text { Vinader-Caerols et } \\
\text { al., } 2002 \\
\end{array}$ \\
\hline OF1 & M & 5,20 & $\mathrm{C}$ & Pre-training & - & & & & & Parra et al., 2000 \\
\hline OF1 & M & 10 & C & Pre-training & 0 & & & & & Parra et al., 2000 \\
\hline CD1 & $\mathrm{M}, \mathrm{F}$ & 25 & A & Pre-training & - & & & & $0 \mathrm{~b}$ & Arenas et al., 2006 \\
\hline CD1 & M & 25 & A & Pre-test & + & & & & $0 \mathrm{~b}$ & Arenas et al., 2006 \\
\hline CD1 & $\mathrm{F}$ & 25 & A & Pre-test & 0 & & & & $0 \mathrm{~b}$ & Arenas et al., 2006 \\
\hline CD1 & $\mathrm{M}, \mathrm{F}$ & 25 & A & $\begin{array}{l}\text { Pre-training and } \\
\text { Pre-test }\end{array}$ & 0 & & & & $0 \mathrm{~b}$ & Arenas et al., 2006 \\
\hline
\end{tabular}

Abbreviations: $\mathrm{Tr} .=$ Treatment; $\mathrm{SDL}=$ state dependent learning; $\mathrm{M}=$ male; $\mathrm{F}=$ female; $\mathrm{A}=$ Acute administration; $\mathrm{SC}=$ Subchronic administration ( 5 days); $\mathrm{C}=$ Chronic administration $(21$ days); $0=$ No effect; - = impairment; + = improvement; $\mathrm{SL}=$ spatial learning; $\mathrm{a}=$ memorization deficit; $\mathrm{b}=$ memorization deficit and performance facilitation.

Table 2. Effects of different doses of maprotiline on inhibitory avoidance learning, activity, anxiety and SDL in mice. 
3. Effects of subchronic administration of maprotiline $(15,20$ and $25 \mathrm{mg} / \mathrm{kg})$ on spatial learning and general activity in male and female CD1 mice in the Morris water maze (Vinader-Caerols et al., 2002). In the acquisition phase, maprotiline (15 and $25 \mathrm{mg} / \mathrm{kg}$ ) impaired learning in males but not in females. Sex differences were not found in the control group in this phase. In the retention phase, all three doses of maprotiline rectified the sex differences observed in the control group. In the general activity test, all three doses of maprotiline decreased activity and removed the sex differences found in the control group. This sexual dimorphism in the effects of maprotiline on spatial learning is in accordance with the findings of studies of the effects of antidepressants and antipsychotics on different learning tasks in mice. When this dimorphism is present, the drug effect is observed only in males or, if present in males and females, is stronger in the former.

4. Study of potential SDL with maprotiline $(25 \mathrm{mg} / \mathrm{kg})$ following the same procedure as that used for amitriptyline (Arenas et al., 2006). The results were interpreted as simultaneous memorization deficit and performance facilitation due to motor impairment. Similarly to that observed with amitriptyline, males treated with maprotiline showed a slightly higher deterioration than females in their performance.

\subsection{Fluoxetine}

Table 3 summarizes the results and some procedural details of the experiments with fluoxetine. They are grouped below in three categories: 1) Effects of acute administration of fluoxetine on IA; 2) Effects of chronic administration of fluoxetine on IA; 3) Study of potential state-dependent learning.

1. Effects of acute administration of fluoxetine $(5,10$ and $20 \mathrm{mg} / \mathrm{kg}$ ) on memory consolidation in male and female OF1 mice (Monleón et al., 2001). The drug was administered immediately after the training session and there was a four-day interval between sessions. The results confirmed IA learning in all the treatment groups. Fluoxetine did not impair memory consolidation in any of the subjects; even the animals treated with the highest dose showed significantly increased response latencies of IA compared with those treated with the lowest dose or saline. As the drug was administered immediately after the training session these results cannot be attributed to unspecific effects, which occur when drugs are administered before the training session (McGaugh, 1989). Sex differences in this task were observed, with females performing better. However, the drug's effects were not sexually dimorphic: sex differences were observed in control animals and they remained with every dose of fluoxetine. Analysis of the locomotor activity of the animals did not reveal any significant differences between the treatment groups. In another experiment, acute doses of fluoxetine (10, 15 and $20 \mathrm{mg} / \mathrm{kg}$ ) were tested in male and female CD1 mice (Parra et al., 2010). The drug was administered 30 min before the training phase and the test phase was carried out $24 \mathrm{~h}$ later. Acquisition and consolidation phases of IA not were impaired by fluoxetine. In addition, the analysis of fluoxetine revealed that females exhibited longer test latencies than males, irrespectively of the pharmacological treatment they had received. The very minor sex differences detected in the present study are in accordance with existing evidence in the literature which suggest that differences observed in the effects of psychotropic medication on the memory of mice are generally stronger among males while IA tends to be more pronounced in females. 


\begin{tabular}{|l|c|c|c|c|c|c|c|c|}
\hline \hline Strain & Sex & $\begin{array}{c}\text { Doses } \\
(\mathrm{mg} / \mathrm{kg})\end{array}$ & Tr. & Administration & Learning & Activity & SDL & Reference \\
\hline \hline OF1 & M, F & 5,10 & A & Post-training & 0 & 0 & & Monleón et al., 2001 \\
\hline \hline OF1 & M, F & 20 & A & Post-training & + & 0 & & Monleón et al., 2001 \\
\hline \hline CD1 & M, F & $10,15,20$ & A & Pre-training & 0 & & & Parra et al., 2010 \\
\hline \hline CD1 & M & 20 & C & Pre-training & - & 0 & Monleón et al., 2002 \\
\hline \hline CD1 & F & 20 & C & Pre-training & 0 & 0 & & Monleón et al., 2002 \\
\hline \hline CD1 & M, F & 20 & C & Post-training & 0 & & Monleón et al., 2002 \\
\hline \hline CD1 & M, F & 15 & A & Pre-training & 0 & & 0 & Arenas et al., 2006 \\
\hline \hline CD1 & M & 15 & A & Pre-test & 0 & & 0 & Arenas et al., 2006 \\
\hline \hline CD1 & F & 15 & A & Pre-test & + & & 0 & Arenas et al., 2006 \\
\hline \hline CD1 & M, F & 15 & A & Pre-training and pre-test & 0 & & 0 & Arenas et al., 2006 \\
\hline \hline
\end{tabular}

Abbreviations: $\mathrm{Tr} .=$ Treatment; $\mathrm{SDL}=$ state dependent learning; $\mathrm{M}=$ male; $\mathrm{F}=$ female; $\mathrm{A}=$ Acute administration; $\mathrm{SC}=$ Subchronic administration $(5$ days $) ; \mathrm{C}=$ Chronic administration $(21$ days $) ; 0=$ No effect; - = impairment; + = improvement; $\mathrm{a}=$ memorization deficit; $\mathrm{b}=$ memorization deficit and performance facilitation.

Table 3. Effects of different doses of fluoxetine on inhibitory avoidance learning, activity and SDL in mice.

2. Effects of chronic administration of fluoxetine $(20 \mathrm{mg} / \mathrm{kg})$ on IA in male and female CD1 mice (Monleón et al., 2002). In Experiment 1, the drug was administered for 21 days before the training session, whereas in Experiment 2, other subjects were subjected to the same treatment schedule, only that it began $24 \mathrm{~h}$ after the training session. The comparison of test versus training latencies revealed a deterioration of memory after pre-training administration of fluoxetine (Experiment 1) in males but not females. Sex differences in this task were also observed in Experiment 1, with females showing a better performance. Sex differences were evident in controls as well as in treated animals. The locomotor activity of the animals was also analysed in Experiment 1 and showed no statistically significant differences in this measure between treated and nontreated groups. Due to the absence of sex differences in the effects of fluoxetine on this measure, the sex differences observed in the effects of the drug on IA cannot have been attributable to non-specific effects on locomotor activity. The lack of an effect of posttraining administration of fluoxetine (Experiment 2) constitutes additional support for the idea that the effect on IA observed in Experiment 1 was specifically related to learning and memory. In summary, we can affirm that fluoxetine impairs IA in chronic pre-training but not in post-training administration.

3. Study of potential SDL with fluoxetine $(15 \mathrm{mg} / \mathrm{kg})$, following the same procedure as that employed for amitriptyline and maprotiline (Arenas et al., 2006). Fluoxetine did not produce any deteriorating effect on conditioning. 


\section{Conclusions}

In order to construct a global perspective, the results discussed in this review can be summarised as follows:

- In general, acute pre-training administration of amitriptyline and maprotiline impairs the acquisition of IA at a wide range of doses, while fluoxetine does not produce any effect.

- Acute post-training administration produces ambiguous results. Amitriptyline can have an undermining effect or an absence of effects. Maprotiline does not exert any effects and fluoxetine only produces an improvement of memory consolidation at a high dose.

- Chronic treatment has an effect on pre-training administration of amitriptyline and fluoxetine. Males are more affected than females with these antidepressants, with an impairment of the acquisition of IA being observed at high doses. Maprotiline, which in chronic administration was tested only pre-training, showed a biphasic effect: the lowest and the highest doses impair the acquisition of the IA but not the intermediate dose.

- Maprotiline and amitriptyline at high doses reduce locomotor activity. With respect to instrumental performance, the decrease in activity observed does not appear to influence the performance of animals in the test phase of IA learning, as they cross the compartment in less time than controls. This is contrary to what would be expected (i.e., that if performance of certain animals is affected, they would show longer test latencies). Furthermore, there is a pharmacokinetic reason for ruling out a locomotor effect of these drugs in the avoidance test phase, as the interval between injection of the drug and the behavioural test was sufficient for the drug to have been eliminated. Therefore, the IA impairment produced by maprotiline and amitriptyline is not shadowed by their effects on activity. Fluoxetine is the only drug which does not produce any effects on locomotor activity.

- The effects on anxiety were tested with maprotiline and amitriptyline and only the highest dose of maprotiline produced an anxiogenic effect in female subjects. The same dose of maprotiline also produced an analgesic effect in both male and female mice. The effects of this dose on IA learning could be shadowed by its effects on anxiety and analgesia, and so this is not a suitable dose to be used in the study of maprotiline and IA memory in mice.

- SDL is a useful behavioural model to explain the influence of drugs on memory, and more specifically for the study of memory-retrieval mechanisms (Arkhipov, 1999). SDL is employed to refer to behavioural responses learnt while animals are under the influence of a centrally acting drug, as thereafter animals perform most efficiently only when the same drug condition is re-established (Overton, 1974, 1984). The antidepressants tested affect the acquisition/consolidation but not the retrieval process in IA learning. In conclusion, our study shows that the effects of the antidepressants amitriptyline, maprotiline and fluoxetine are not state-dependent: the drugs' actions on IA learning affect acquisition/consolidation but not the retrieval process. Nevertheless, there are some differences between the three antidepressants. Amitriptyline produces a memorization deficit in the IA task, while maprotiline exerts a less obvious effect on the consolidation of memory due to its interference with motor effects, and fluoxetine has no impairing effects on learning. We believe that the differences observed in the effects of these three 
antidepressants on IA memory can be explained by their distinct action on the cholinergic system; i.e., the higher the anticholinergic effect, the greater the memory impairment. The results reported here were obtained under acute treatment, and therefore should not be considered a model of clinical treatment, since antidepressants are chronically administered when applied for therapeutic purposes. However, these findings and those of similar studies contribute to a better understanding of the effects of antidepressants on memory processes, which is crucial for improving their prescription in humans.

- The neurotransmitters histamine, acetylcholine and serotonin have been related with the acquisition and consolidation of memory in IA tasks (Babar et al., 2002; Eidi et al., 2003). The amnesic effect produced by amitriptyline in our laboratory was not confined to the cholinergic system (Monleón et al., 2009; Urquiza, 2007). In fact, the serotonergic system was also involved (Parra et al., 2010), as the joint administration of amitriptyline and fluoxetine at doses which did not have an effect when given alone had a clear impairing effect. We believe this represents a synergistic effect of both drugs, which confirms the implication of the serotonergic system in the impairing effects of amitriptyline on IA in mice. The histaminergic system does not seem to be implicated in this impairing effect of amitriptyline (Ferrer-Añó, 2008).

- The use of both male and female subjects is especially relevant in animal studies of disorders in which sex differences have been described in human beings. In fact, epidemiological studies have shown that the lifetime prevalence of major depressive disorder in women $(21.3 \%)$ is almost twice that in men $(12.7 \%)$, and this ratio has been documented in different countries and ethnic groups (Noble, 2005). These sex differences have been observed in the prevalence of mental disorders as well as in responses to treatment (Frackiewicz et al., 2000). Sex differences in control subjects were observed in some experiments carried out in our laboratory, with females exhibiting longer latencies than males in the test phase, thus indicating a more effective IA learning in females. We have also detected sex differences in the effects of amitriptyline, maprotiline and fluoxetine on IA learning. When this dimorphism is present, the drug effect is generally stronger in males than in females.

- Most preclinical trials are carried out with males only due to a supposedly higher variability among females, not confirmed by data from our laboratory (Parra et al., 1999). This is a somewhat inappropriate policy given that women consume more psychotropic medication than men (Cafferata et al., 1983). Furthermore, there are important reasons for evaluating the impact of antidepressants on both male and female subjects:

a. Gender differences in the epidemiology of depression, which is more common in women than in men (American Psychiatric Association, 1994; Kornstein, 1997).

b. Gender differences in the efficacy of some antidepressants, such as maprotiline and fluoxetine (Martényi et al., 2001).

c. Differences in pharmacokinetics and pharmacodynamics between men and women have been reported for several drugs, including antidepressants (Frackiewicz et al., 2000; Gandhi et al., 2004).

\section{Acknowledgements}

The authors wish to thank the Spanish "Ministerio de Ciencia y Tecnología" and the European Regional Development Fund (ERDF) (Grant, BSO2003-07163), the Spanish 
"Ministerio de Ciencia e Innovación" (PSI2008-06116) and the "Universitat de València" (UV-AE-07-564) for funding the work reviewed herein (P.I.: Andrés Parra). Ongoing research is funded by the Spanish "Ministerio de Ciencia e Innovación" (PSI2008-06116; P.I.: Andrés Parra) and "Generalitat Valenciana" (Prometeo/2011/048; P.I.: Alicia Salvador). They also wish to thank Mr. Brian Normanly for his editorial assistance and Encarna Rama Galdón and Marta Arsenal Castillo for their help with the figures.

\section{References}

Amado-Boccara, I.; Gougoulis, N.; Poirier, M.F.; Galinowski, A. \& Lo^o, H. (1995). Effects of antidepressants on cognitive functions: A review. Neuroscience $\mathcal{E}$ Biobehavioral Reviews, Vol.19, pp. 479-493.

American Psychiatric Association (1994). DSM IV-Diagnostic and Statistical Manual of Mental Disorders. Fourth ed. American Psychiatric Association, Washington D.C.

Arenas, M.C.; Vinader-Caerols, C.; Monleón, S.; Martos, A.J.; Everss, E.; Ferrer-Añó, A. \& Parra, A. (2006). Are the effects of the antidepressants amitriptyline, maprotiline, and fluoxetine on inhibitory avoidance state-dependent? Behavioural Brain Research, Vol.166, pp. 150-158.

Arkhipov, V.I. (1999). Memory dissociation: the approach to the study of retrieval process. Behavioural Brain Research, Vol.106, pp. 39-46.

Babar, E.; Melik, E.; Ozgunen, T.; Kaya, M. \& Polat, S. (2002). Effects of excitotoxic median raphe lesions on scopolamine-induced working memory deficits in inhibitory avoidance. International Journal of Neuroscience, Vol.112, pp. 525-35.

Baldessarini, R.J. (2001). Drugs and the treatment of psychiatric disorders: depression and anxiety disorders, In: Goodman \& Gilman's The pharmacological basis of therapeutics, 10th edition, J.G. Hardman, L.E. Limbird \& A.G. Gilman, (Eds.), pp. 447-483, McGraw-Hill, New York.

Bert, B.; Fink, H.; Rothe, J.; Walstab, J. \& Bönisch, H. (2008). Learning and memory in 5HT(1A)-receptor mutant mice. Behavioural Brain Research, Vol.195, pp. 78-85.

Beasley, C.M.; Masica, D.N. \& Potvin, J.H. (1992). Fluoxetine: a review of receptor and functional effects and their clinical implications. Psychopharmacology, Vol.107, pp. 110.

Boccia, M.M.; Blake, M.G.; Acosta, G.B. \& Baratti, C.M. (2003). Atropine, an anticholinergic drug, impairs memory retrieval of a high consolidated avoidance response in mice. Neuroscience Letters, Vol.345, pp. 97-100.

Cafferata, G.L.; Kasper, J. \& Bernstein, A. (1983). Family roles, structure and stressors in relation to sex differences in obtaining psychotropic drugs. Journal of Health $\mathcal{E}$ Social Behavior, Vol.24, pp. 132-143.

Campbell, S.; Marriott, M.; Nahmias, C. \& MacQueen, G.M. (2004). Lower hippocampal volume in patients suffering from depression: a meta-analysis. American Journal of Psychiatry, Vol.161, pp. 598-607.

Castaneda, A.E.; Tuulio-Henriksson, A.; Marttunen, M.; Suvisaari, J. \& Lönnqvist, J. (2008). A review on cognitive impairments in depressive and anxiety disorders with a focus on young adults. Journal of Affective Disorders, Vol.106, pp. 1-27.

Choi, R.L.; Roch, M. \& Jenden, D.J. (1973). A regional study of acetylcholine turnover in rat brain and the effects of oxotremorine. Proceedings of the Western Pharmacology Society, Vol.16, pp. 188-190. 
Dudra-Jastrzebska, M.; Andres-Mach, M.M.; Łuszczki, J.J. \& Czuczwar, S.J. (2007). Mood disorders in patients with epilepsy. Pharmacological Reports, Vol.59, pp. 369-378.

Duman, R.S.; Malberg, J. \& Thome, J. (1999). Neural plasticity to stress and antidepressant treatment. Biological Psychiatry, Vol.46, pp. 1181-1191.

Duric, V. \& McCarson, K.E. (2006). Effects of analgesic or antidepressant drugs on pain- or stress-evoked hippocampal and spinal neurokinin-1 receptor and brain-derived neurotrophic factor gene expression in the rat. Journal of Pharmacology and Experimental Therapeutics, Vol.319, pp. 1235-1243.

Eidi, M.; Zarrindast, M.R.; Eidi, A.; Oryan, S. \& Parivar, K. (2003). Effects of histamine and cholinergic systems on memory retention of passive avoidance learning in rats. European Journal of Pharmacology, Vol.465, pp. 91-96.

Everitt, B.J. \& Robbins, T.W. (1997). Central cholinergic systems and cognition. Annual Review of Psychology, Vol.48, pp. 649-684.

Everss, E.; Arenas, M.C.; Vinader-Caerols, C.; Monleón, S. \& Parra, A. (1999). Effects of amitriptyline on memory consolidation in male and female mice. Medical Science Research, Vol.27, pp. 237-239.

Everss, E.; Arenas, M.C.; Vinader-Caerols, C.; Monleón, S. \& Parra, A. (2005). Piracetam counteracts the effects of amitriptyline on inhibitory avoidance in CD1 mice. Behavioural Brain Research, Vol.159, pp. 235-242.

Ferrer-Añó, A. (2008). Estudio de la mediación del sistema histaminérgico en el efecto producido por la amitriptilina sobre la evitación inhibitoria en ratones. Doctoral Thesis, University of Valencia, Spain.

File, S.E. (2001). Factors controlling measures of anxiety and responses to novelty in the mouse. Behavioural Brain Research, Vol.125, pp. 151-157.

Frackiewicz, E.J.; Sramek, J.J. \& Cutler, N.R. (2000). Gender differences in depression and antidepressant pharmacokinetics and adverse events. The Annals of Pharmacotherapy, Vol.34, pp. 80-88.

Frazer, A. (1997). Pharmacology of antidepressants. Journal of Clinical Psychopharmacology, Vol.17(suppl 1), pp. 2S-18S.

Gandhi, M.; Aweeka, F.; Greenblatt, R.M. \& Blaschke, T.F. (2004). Sex differences in pharmacokinetics and pharmacodynamics. Annual Review of Pharmacology and Toxicology, Vol.44, pp. 499-523.

Gareri, P.; Falconi, U.; de Fazio, P. \& de Sarro, G. (2000). Conventional and new antidepressant drugs in the elderly. Progress in Neurobiology, Vol.61, pp. 353-396.

Gold, P.E. (1986). The use of avoidance training in studies of modulation of memory storage. Behavioral and Neural Biology, Vol.46, pp. 87-98.

González-Pardo, H.; Conejo, N.M.; Arias, J.L.; Monleón, S.; Vinader-Caerols, C. \& Parra, A. (2008). Changes in brain oxidative metabolism induced by inhibitory avoidance learning and acute administration of amitriptyline. Pharmacology Biochemistry and Behavior, Vol.89, pp. 456-462.

Gouliaev, A.H. \& Senning, A. (1994). Piracetam and other structurally related nootropics. Brain Research Reviews, Vol.19, pp. 180-222.

Grüter, W. \& Pöldinger, W. (1982). Maprotiline. Modern Problems of Pharmacopsychiatry, Vol.18, pp. 17-48.

Harvey, A.T.; Rudolph, R.L. \& Preskorn, S.H. (2000). Evidence of the dual mechanisms of action of venlafaxine. Archives of General Psychiatry, Vol.57, pp. 503-509. 
Hascoët, M.; Bourin, M.; Colombel, M.C.; Fiocco, A.J. \& Baker, G.B. (2000). Anxiolytic-like effects of antidepressants after acute administration in a four-plate test in mice. Pharmacology Biochemistry and Behavior, Vol.65, pp. 339-344.

Hebb, D.O. (1949). The organization of behavior. John Wiley \& Sons, Inc., New York.

Heise, G.A. (1981). Learning and memory facilitators: Experimental definition and current status. Trends in Pharmacological Sciences, Vol.2, pp. 158-160.

Hertz, L.; Chen, Y.; Gibbs, M.E.; Zang, P. \& Peng, L. (2004). Astrocytic adrenoceptors: a major drug target in neurological and psychiatric disorders? Current Drug Targets CNS \& Neurological Disorders, Vol.3, pp. 239-267.

Humphreys, M.R. \& Reinberg, Y.E. (2005). Contemporary and emerging drug treatments for urinary incontinence in children. Pediatric Drugs, Vol.7, 151-162.

Introini-Collison, I.B. \& Baratti, C.M. (1992). Memory-modulatory effects of centrally acting noradrenergic drugs: possible involvement of brain cholinergic mechanisms. Behavioral and Neural Biology, Vol.57, pp. 248-255.

Izquierdo, I. \& McGaugh, J.L. (2000). Behavioural pharmacology and its contribution to the molecular basis of memory consolidation. Behavioural Pharmacology, Vol.11, pp. 517534.

Kandel, E.R. (2001). The molecular biology of memory storage: a dialogue between genes and synapses. Science, Vol.294, pp. 1030-1038.

Kasper, S. \& McEwen, B.S. (2008). Neurobiological and clinical effects of the antidepressant tianeptine. CNS Drugs, Vol.22, pp. 15-26.

Konradi, C. \& Heckers, S. (2001). Antipsychotic drugs and neuroplasticity: insights into the treatment and neurobiology of schizophrenia. Biological Psychiatry, Vol.50, pp. 729742.

Kornstein, S. (1997). Gender differences in depression: implications for treatment. Journal of Clinical Psychiatry, Vol.58, pp. 2-18.

Lamberty, Y. \& Gower, A.J. (1990). Age-related changes in spontaneous behavior and learning in NMRI mice from maturity to middle age. Physiology and Behavior, Vol. 47, pp. 1137-1144.

Lister, R.G. (1987). The use of a plus-maze to measure anxiety in the mouse. Psychopharmacology, Vol.92, pp. 180-185.

McGaugh, J.L. (1989). Dissociating learning and performance: Drug and hormone enhancement of memory storage. Brain Research Bulletin, Vol.23, pp. 339-345.

McGaugh, J.L. \& Izquierdo, I. (2000). The contribution of pharmacology to research on the mechanisms of memory formation. Trends in Pharmacological Sciences, Vol.21, pp. 208-210.

Martényi, F.; Dossenbach, M.; Mraz, K. \& Metcalfe, S. (2001). Gender differences in the efficacy of fluoxetine and maprotiline in depressed patients: a double-blind trial of antidepressants with serotonergic or norepinephrine reuptake inhibition profile. European Neuropsychopharmacology, Vol.11, pp. 227-232.

Mitchell, H.A.; Ahern, T.H.; Liles, L.C.; Javors, M.A. \& Weinshenker, D. (2006). The effects of norepinephrine transporter inactivation on locomotor activity in mice. Biological Psychiatry, Vol.60, pp. 1046-1052.

Monleón, S.; Casino, A.; Vinader-Caerols, C. \& Arenas MC. (2001). Acute effects of fluoxetine on inhibitory avoidance consolidation in male and female OF1 mice. Neuroscience Research Communications, Vol.28, pp. 123-130. 
Monleón, S.; Urquiza, A.; Arenas, M.C.; Vinader-Caerols, C. \& Parra, A. (2002). Chronic administration of fluoxetine impairs inhibitory avoidance in male but not female mice. Behavioural Brain Research, Vol.136, pp. 483-488.

Monleón, S.; Vinader-Caerols, C.; Arenas, M.C. \& Parra, A. (2008). Antidepressant drugs and memory: insights from animal studies. European Neuropsychopharmacology, Vol.18, pp. 235-248.

Monleón, S.; Urquiza, A.; Vinader-Caerols, C. \& Parra, A. (2009). Effects of oxotremorine and physostigmine on the inhibitory avoidance impairment produced by amitriptyline in male and female mice. Behavioural Brain Research, Vol.205, pp. 367371.

Morris, R.G. (1984). Development of a water-maze procedure for studying spatial leaming in the rat. Journal of Neuroscience Methods, Vol.11, pp. 47-60.

Morris, R.G.; Moser, E.I.; Riedel, G.; Martin, S.J.; Sandin, J.; Day, M. \& O'Carroll, C. (2003). Elements of a neurobiological theory of the hippocampus: the role of activitydependent synaptic plasticity in memory. Philosophical Transactions of the Royal Society of London. Series B, Biological Sciences, Vol.358, pp. 773-786.

Myhrer, T. (2003). Neurotransmitter systems involved in learning and memory in the rat: a meta-analysis based on studies of four behavioral tasks. Brain Research Reviews, Vol.41, pp. 268-287.

Nemeroff, C.B. \& Vale, W.W. (2005). The neurobiology of depression: inroads to treatment and new drug discovery. Journal of Clinical Psychiatry, Vol.66: 5-13.

Noble, R.E. (2005). Depression in women. Metabolism, Vol.54, pp. 49-52.

Overton, D.A. (1974). Experimental methods for the study of state-dependent learning. Federation Proceedings, Vol.54, 1800-1813.

Overton, D.A. (1984). State dependent learning and drug discriminations. In: Handbook of Psychopharmacology, L.L. Iversen, S.D. Iversen \& S.H. Snyder, (Eds.), pp. 59-127, Plenum Press, New York.

Owens, M.J.; Morgan, W.N.; Plott, S.J. \& Nemeroff, C.B. (1997). Neurotransmitter receptor and transporter binding profile of antidepressants and their metabolites. Journal of Pharmacology and Experimental Therapeutics, Vol.283, pp. 1305-1322.

Paizanis, E.; Hamon, M. \& Lanfumey, L. (2007). Hippocampal neurogenesis, depressive disorders, and antidepressant therapy. Neural Plasticity, Vol.2007, pp. 73754-73760.

Parra, A. (2003). A common role for psychotropic medications: memory impairment. Medical Hypotheses, Vol.60, pp. 133-142.

Parra, A.; Arenas, M.C.; Monleón, S.; Vinader-Caerols, C. \& Simón, V.M. (1999). Sex differences in the effects of neuroleptics on escape-avoidance behavior in mice: a review. Pharmacology Biochemistry and Behavior, Vol.64, pp. 813-820.

Parra, A.; Monleón, S.; Arenas, M.C. \& Vinader-Caerols, C. (2000). Effects of acute and chronic maprotiline administration on inhibitory avoidance in male mice. Behavioural Brain Research, Vol.109, pp. 1-7.

Parra, A.; Everss, E.; Monleón, S.; Vinader-Caerols, C. \& Arenas, M.C. (2002). Effects of acute amitriptyline administration on memory, anxiety and activity in male and female mice. Neuroscience Research Communications, Vol.31, pp. 135-144.

Parra, A.; Everss, E.; Arenas, M.C.; Vinader-Caerols, C. \& Monleón, S. (2006). Amitriptyline administered after consolidation of inhibitory avoidance does not affect memory retrieval. Psicothema, Vol.18, pp. 514-518. 
Parra, A.; Vinader-Caerols, C.; Ferrer-Añó, A.; Urquiza, A. \& Monleón, S. (2009). The effect of amitriptyline on inhibitory avoidance in mice is dose-dependent. Psicothema, Vol.21, pp. 528-530.

Parra, A.; Ferrer-Añó, A.; Fuentes, C.; Monleón, S. \& Vinader-Caerols, C. (2010). Effects of co-administration of amitriptyline and fluoxetine on inhibitory avoidance in mice. Behavioural Brain Research, Vol.214, pp. 343-348.

Passani, M.B.; Bacciottini, L.; Mannaioni, P.F. \& Blandina, P. (2000). Central histaminergic system and cognition. Neuroscience \& Biobehavioral Reviews, Vol.24, pp. 107-113.

Pinder, R.M.; Brogden, R.N.; Speight, T.M. \& Avery, G.S. (1977). Maprotiline, a review of its pharmacological properties and therapeutic efficacy in mental depressive states. Drugs, Vol.13, pp. 321-352.

Pittenger, C. \& Duman, R.S. (2008). Stress, depression, and neuroplasticity: a convergence of mechanisms. Neuropsychopharmacology, Vol.33, pp. 88-109.

Prell, G.D.; Hough, L.B.; Khandelwal, J. \& Green, J.P. (1996). Lack of a precursor-product relationship between histamine and its metabolites in brain after histidine loading. Journal of Neurochemistry, Vol.67, pp. 1938-1944.

Redrobe, J.P. \& Bourin, M. (1997). Partial role of 5-HT2 and 5-HT3 receptors in the activity of antidepressants in the mouse forced swimming test. European Journal of Pharmacology, Vol.325, pp. 129-135.

Richelson, E. \& Nelson, A. (1984). Antagonism by antidepressants of neurotransmitter receptors of normal human brain in vitro. Journal of Pharmacology and Experimental Therapeutics, Vol.230, pp. 94-102.

Richelson, E. (2001). Pharmacology of antidepressants. Mayo Clinic Proceedings, Vol.76, pp. 511-527.

Richelson, E. (2003). Interactions of antidepressants with neurotrasmitter transpoters and receptors and their clinical relevance. Journal of Clinical Psychiatry, Vol.64, pp. 5-12.

Rodgers, R.J. \& Johnson, N.J. (1995). Factor analysis of spatiotemporal and ethological measures in the murine elevated plus-maze test of anxiety. Pharmacology Biochemistry and Behavior, Vol.52, pp. 297-303.

Sahay, A. \& Hen, R. (2007). Adult hippocampal neurogenesis in depression. Nature Neuroscience, Vol.10, pp. 1110-1115.

Schatzberg, A.F. (2000). New indications for antidepressants. Journal of Clinical Psychiatry, Vol.61, pp. 9-17.

Sindrup, S.H.; Otto, M.; Finnerup, N.B. \& Jensen, T.S. (2005). Antidepressants in the treatment of neuropathic pain. Basic \& Clinical Pharmacology \& Toxicology, Vol.96, pp. 399-409.

Stahl, S.M. (1998). Basic psychopharmacology of antidepressants. Part 1: Antidepressants have seven distinct mechanism of action. Journal of Clinical Psychiatry, Vol.59, pp. 514.

Stahl, S.M. (2008). Stahl's essential psychopharmacology. Neuroscientific basis and practical aplications. $3^{\text {rd }}$ edition, Cambridge University Press, New York.

Stark, P.; Fuller, R.W. \& Wong, D.T. (1985). The pharmacologic profile of fluoxetine. Journal of Clinical Psychiatry, Vol.46, pp. 7-13.

Taylor, P. (2001). Anticholinesterase agents, In: Goodman \& Gilman's The pharmacological basis of therapeutics, 10th edition, J.G. Hardman, L.E. Limbird \& A.G. Gilman, (Eds.), pp. 175-191, McGraw-Hill, New York. 
Thompson, P.J. (1991). Antidepressants and memory: a review. Human Psychopharmacology: Clinical and Experimental, Vol.6, pp. 79-90.

Tsukahara, T.; Iihara, K.; Hashimoto, N.; Nishijima, T. \& Taniguchi, T. (1998). Increases in levels of brain-derived neurotrophic factor mRNA and its promoters after transient forebrain ischemia in the rat brain. Neurochemistry International, Vol.33, pp. 201-207.

Urquiza, A. (2007). Estudio de la intervención del sistema colinérgico en el efecto producido por la amitriptilina en una tarea de evitación inhibitoria en ratones machos y hembras. Doctoral Thesis, University of Valencia, Spain.

Vaidya, V.A. \& Duman, R.S. (2001). Depresssion-emerging insights from neurobiology. British Medical Bulletin, Vol.57, pp. 61-79.

Vinader-Caerols, C.; Ferrer-Añó, A.; Arenas, M.C.; Monleón, S. \& Parra, A. (2002). La maprotilina anula las diferencias entre ratones machos y hembras en el laberinto de agua de Morris. Psicothema, Vol.14, pp. 823-827.

Vinader-Caerols, C.; Martos, A.J.; Monleón, S.; Arenas, M.C. \& Parra, A. (2006). Acute effects of maprotiline on learning, anxiety, activity and analgesia in male and female mice. Acta Neurobiologiae Experimentalis, Vol.66, pp. 23-31.

Yanai, K.; Yagi, N.; Watanabe, T.; Itoh, M.; Ishiwata, K.; Ido, T. \& Matsuzawa, T. (1990). Specific binding of $[3 \mathrm{H}]$ pyrilamine to histamine $\mathrm{H} 1$ receptors in guinea pig brain in vivo: determination of binding parameters by a kinetic four-compartment model. Journal of Neurochemistry, Vol 55, pp. 409-420. 


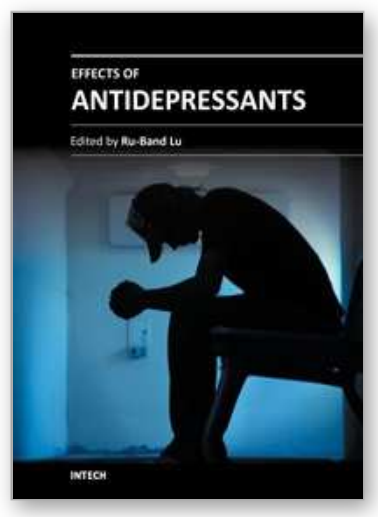

\author{
Effects of Antidepressants \\ Edited by Dr. Ru-Band Lu
}

ISBN 978-953-51-0663-0

Hard cover, 194 pages

Publisher InTech

Published online 29, June, 2012

Published in print edition June, 2012

Over the last fifty years, many studies of psychiatric medication have been carried out on the basis of psychopharmacology. At the beginning, researchers and clinicians found the unexpected effectiveness of some medications with therapeutic effects in anti-mood without knowing the reason. Next, researchers and clinicians started to explore the mechanism of neurotransmitters and started to gain an understanding of how mental illness can be. Antidepressants are one of the most investigated medications. Having greater knowledge of psychopharmacology could help us to gain more understanding of treatments. In total ten chapters on various aspects of antidepressants were integrated into this book to help beginners interested in this field to understand depression.

\title{
How to reference
}

In order to correctly reference this scholarly work, feel free to copy and paste the following:

Concepción Vinader-Caerols, Andrés Parra and Santiago Monleón (2012). Effects of Antidepressants on Inhibitory Avoidance in Mice: A Review, Effects of Antidepressants, Dr. Ru-Band Lu (Ed.), ISBN: 978-953-510663-0, InTech, Available from: http://www.intechopen.com/books/effects-of-antidepressants/effects-ofantidepressants-on-inhibitory-avoidance-in-mice-a-review

\section{INTECH}

open science | open minds

\section{InTech Europe}

University Campus STeP Ri

Slavka Krautzeka 83/A

51000 Rijeka, Croatia

Phone: +385 (51) 770447

Fax: +385 (51) 686166

www.intechopen.com

\section{InTech China}

Unit 405, Office Block, Hotel Equatorial Shanghai

No.65, Yan An Road (West), Shanghai, 200040, China 中国上海市延安西路65号上海国际贵都大饭店办公楼 405 单元

Phone: +86-21-62489820

Fax: $+86-21-62489821$ 
(C) 2012 The Author(s). Licensee IntechOpen. This is an open access article distributed under the terms of the Creative Commons Attribution 3.0 License, which permits unrestricted use, distribution, and reproduction in any medium, provided the original work is properly cited. 